\title{
SiM
}

\section{Incorporating Women's Voices Into Wyoming Rangeland Research and Extension}

\author{
By Hailey Wilmer and Rachel Mealor
}

\section{On the Ground}

- The field of rangeland science and management is working to incorporate women's voices and a better understanding of women's decision-making roles into our research priorities and Extension practices.

- The Wyoming Women in Range program offers a success story of Extension programming designed to encourage women's participation and engagement in rangeland management.

- Further research is needed to understand ranching women's needs and responsibilities as business operators, natural resource managers, wives, mothers, and off-farm wage earners.

Keywords: Extension, Wyoming Women in Range Program, women, needs-based Extension, rangeland Extension, women ranchers.

\section{Incorporando las voces de las mujeres en la investigación y Extensionismo de los pastiza-} les y tierras silvestres de Wyoming

\section{Perspectiva desde el campo:}

- El campo de la ciencia y manejo de los pastizales y tierras silvestres está trabajando para incorporar las voces de las mujeres y lograr un mejor entendimiento de los roles con capacidad de toma de decisiones de las mujeres en nuestras prioridades de investigación y prácticas de Extensionismo.

- El programa de Mujeres de Wyoming en el Pastoreo ofrece una historia de éxito en la programación del Extensionismo diseñada para alentar la participación y compromiso de las mujeres en el manejo de pastizales y tierras silvestres.

- Es necesaria una mayor investigación para entender las necesidades y responsabilidades de las mujeres rancheras como operadoras empresariales, administradoras de recursos naturales, esposas, madres y asalariadas fuera del sector agropecuario.

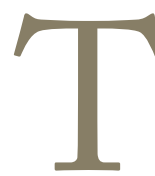
hose of us involved in agriculture are familiar with the alarming "statistic" that the United States only has 2 million agriculturalists. We hear this statement almost as often as we hear that family farms and ranches are the foundation of American agriculture. A closer look at the data collected by the US Census of Agriculture over the past decade sheds new light on both of these statements. Until 2002 the US Census of Agriculture did not collect demographic information on more than one operator on each farm or ranch, even when operating responsibility was shared between two or more people. ${ }^{1}$ With the change in how operators were counted in 2002, we learned that the United States actually had over 3 million operators on 2 million farms and ranches. Over 800,000 of these operators were women. More recent data tell us that women are a growing demographic of farm and ranch operators, accounting for over $30 \%$ of all operators (an 11\% increase from 2002) and $10.4 \%$ (up from $8.4 \%$ ) of primary operators on beef operations in 2007, though women tend to run smaller, more diverse operations. ${ }^{2}$

The census data suggest that rangeland scientists and Extension professionals see the family operation as just that, 
a complex enterprise involving a diverse group of decision makers, male and female. These decision makers bring their own individual, family, and community aspirations to the decision-making process. ${ }^{3,4}$ Ranching women take on caregiving and maternal roles at home while juggling management responsibility on the land, in off-farm enterprises, and in production activities such as harvesting and caring for livestock. ${ }^{5}$

Rangeland-related Extension and research is working to understand and respond to the diverse gender roles of ranching women. Much of the existing literature on women's Extension services notes that Extension programming in the United States and abroad often reflects a gendered division of labor in livestock production by emphasizing women's social and reproductive roles and neglecting roles as agricultural producers, decisionmakers, and land managers. ${ }^{6}$ While rangeland scientists and Extension professionals have sought opportunities to incorporate women's concerns into rangeland Extension and research, these efforts have not been well documented in the literature.

In this paper we describe one such effort to meet the needs of female ranchers through the creation of a women-specific rangeland Extension program in Wyoming. We highlight the outcomes, lessons, and challenges of the program through the Extension educator's perspective. We also discuss what additional steps the field of rangeland science and management must take to further understand, formally acknowledge, and support the role of women in rangeland management.

\section{Wyoming Women in Range Program}

The Wyoming Women in Range is a program that was developed to encourage women's participation and engagement in rangeland management. At previous range management workshops we sometimes observed women ranchers apparently deferring to their husband, father, or brother. This is not a negative observation, but such encounters beg the question of whether these women would speak up more if their husbands/fathers/brothers were not present. We noticed that women appeared to be gaining interest in natural resource activities, so the program provided an excellent opportunity to engage them in rangeland management. These thoughts led to a few overarching questions. Would a program directed at female participation in rangeland management issues be successful? Would providing women a venue to express their thoughts among other women help build their knowledge base and their confidence in that knowledge?

Targeting an all-female audience is not unique to this program. An existing program in Australia is similar in its attention toward female participation in an attempt to build their leadership skills, knowledge, and confidence. The difference, however, is the skills and knowledge being taught so as to increase or validate their confidence (see Leigo, this issue).

Our first step was to convene an advisory group to develop ideas for the program, and to focus specifically on educational opportunities. The advisory group was made up of female landowners and university representatives. Together we developed goals and objectives for the Wyoming Women in Range program. The overall goals were to increase participants' knowledge of rangeland management while promoting the development of a group that will learn together and hold one another accountable in adopting and carrying out sustainable rangeland management activities on their properties. To achieve these goals we developed three main strategies for the program: 1) build a rangeland management curriculum emphasizing the participation of female rangeland landowners and managers, 2) develop and conduct workshops (classroom and field), and 3) evaluate and follow up on workshops to determine adoption of practices and impacts of the program. To measure success of the program we developed an evaluation asking questions about knowledge gained regarding each topic covered, how participants intended to use information gained, what information gaps still existed, and what challenges impeded participants from adopting management strategies presented at the workshop. We asked the participants how and whether the information they gained had an economic impact on their operation. Success was measured by change in knowledge and application of new knowledge on participants' properties. At the beginning of each workshop, participants discussed whether or not they are actually using information from the previous workshop, and if not the reasons why.

The program provided women ranchers and land managers with a scientific foundation in natural resource management. Speakers demonstrated various techniques and strategies to improve the management of their rangelands and presented the scientific basis for why such practices are believed to be effective. It also provided women an opportunity to meet and interact with other women in their community who are interested in natural resource management. The program consisted of workshops that included range management topics of interest or importance to the local community. Due to the variability in the knowledge and experience of participants, the advisory group decided that topics for the first workshop should be basic. Content included plant identification and the development of a grazing plan. Following the first workshop, the curriculum progressed flexibly based on how topics were ranked in the evaluation and topics that best fit the needs and interests of the community in which the workshop was held. Workshop topics to date have included basic plant identification and growth characteristics, developing a grazing plan, weed identification and management, livestock body condition scoring, and vegetation monitoring. Each workshop typically included both a classroom and field component to address different learning styles (auditory, visual, kinesthetic). For example, one community has a very active weed and pest office that works to maintain awareness within the community. This community borders another state, which increases the need for weed awareness and management as uncommon weeds can easily infest an area and move from 


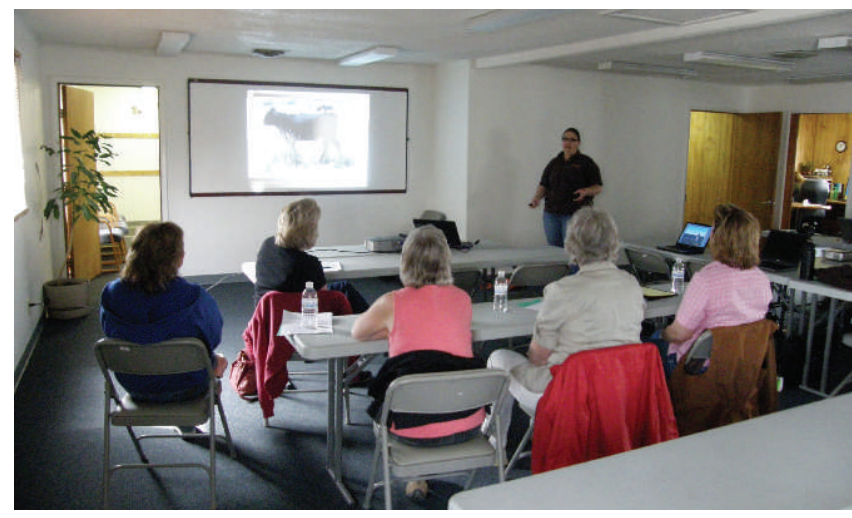

Figure 1. The overall goals of the Wyoming Women in Range program were to increase participants' knowledge of rangeland management while promoting the development of a group that will learn together and hold one another accountable in adopting and carrying out rangeland management practices.

one state to another. Knowing this about that particular community, we were not surprised to hear one of the women suggest weed management as the topic for the second workshop.

By presenting a series of workshops, the program aimed to facilitate the development of a group of women who would exchange information with one another, and provide mutual assistance and encouragement with implementing rangeland management practices on their properties (Fig. 1).
Have the Workshops Been Successful?

The Wyoming Women in Range programs have been interactive and hands-on in a relaxed environment with a sense of community among group members. Initial evaluations were positive. Evaluations from our first workshop held in southwest Wyoming showed that a majority of participants categorized the workshop as excellent and reported that their questions were answered. Comments such as "enjoy the opportunity to network with other female professionals" and "I like having workshops for women" support the idea that participants enjoyed having a venue to share ideas and interact with other women in their community. Time constraints and difficulty getting started were the main reasons participants reported for not implementing land management practices. In the workshops that have been held, about half of the participants (5 out of 10) were consistent attendees and participated in all four workshops in the same community. As workshops continued, it appears that trust and the development of relationships have been an outcome of repeated contacts of the same group of participants. The level of participation (consistently about 10 individuals) has been good for our pilot area workshops. However, when we tried to initiate a Wyoming Women in Range program in another location, it met with limited success due to lack of attendance. After talking with women in that community we learned that the timing of the workshop was the primary barrier to participation. One important lesson is that it is

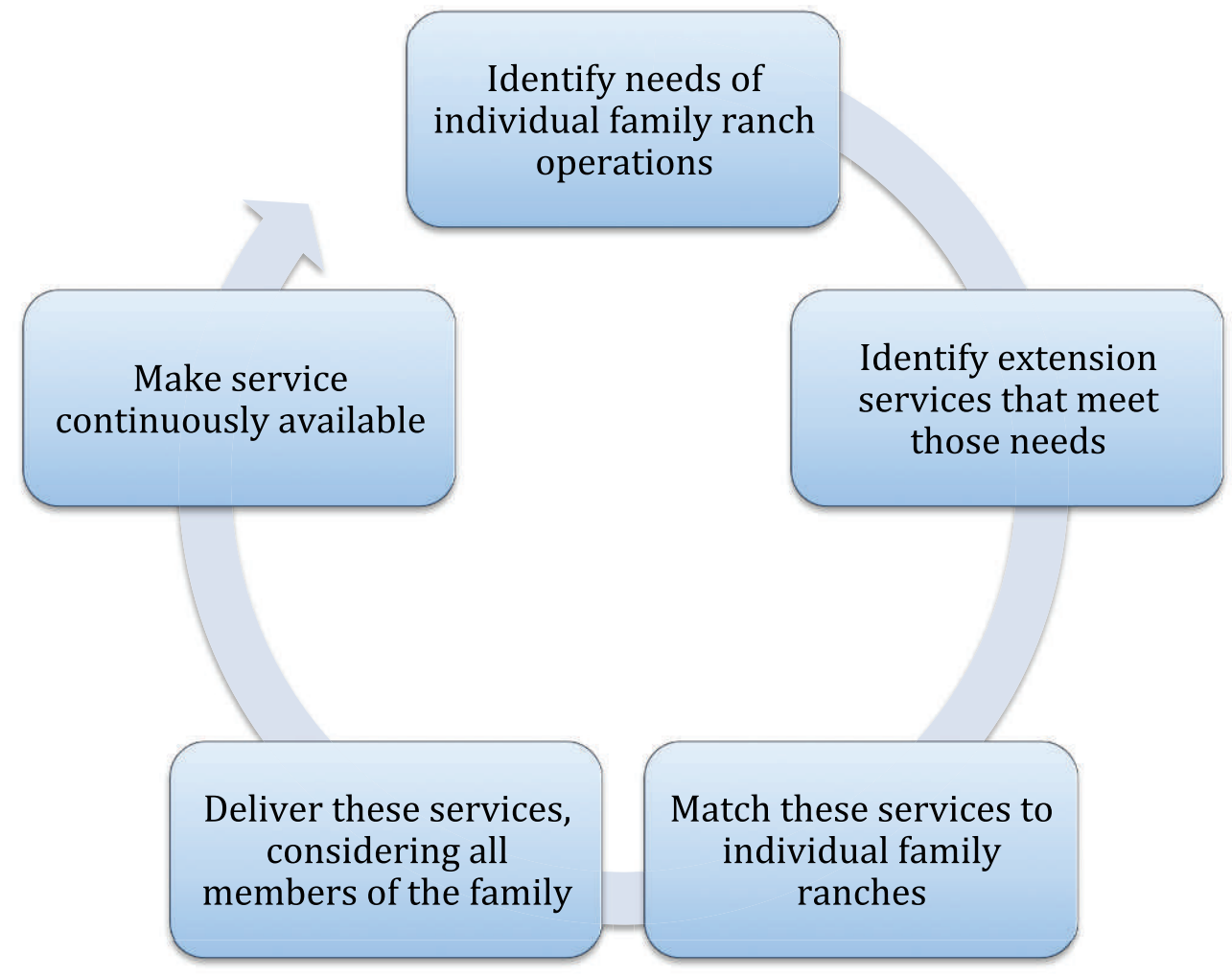

Figure 2. Fulton and Vanclay's needs-based Extension model. ${ }^{9}$ This design supports healthy rangeland ecosystems and rural communities from the bottom up by considering the complex sociological elements of a family ranching operation. It provides information to different members of the operation when they need or want that information. 
crucial that the logistics of each workshop be tailored to the women of each community. For example, if many of the women work off-ranch, an evening workshop may provide the best opportunity for participation. There may also be women who cannot find or afford childcare. In Australia (see Leigo, this issue), a similar effort found success by providing daycare during the sessions. This strategy may be a way to increase the participation at the Wyoming Women in Range program.

The Wyoming Women in Range program is fairly new, but we plan to continue to expand the program throughout the state of Wyoming. The pilot area is the only community currently participating in the program. However, workshops have been scheduled to begin in another county in Wyoming. We hope the program will continue to foster trust and increase the development of strong relationships among women who participate. Ideally, participants within the group will begin to hold one another accountable and help each other implement sustainable rangeland management.

\section{Next Steps}

The Wyoming Women in Range program is a step toward recognizing and serving a growing demographic of rangeland managers in Wyoming. There is ongoing discussion in the field of rangeland science and management as to how we might best incorporate women as leaders in rangeland stewardship into our research priorities and Extension practices. For Extension practitioners, the next step is a concerted effort to shift our Extension design from the technologytransfer model of Extension to a needs-based model. ${ }^{7}$ Like the field of rangeland management for much of the 20th century, the technology-transfer philosophy behind much of our Extension programming is focused on production efficiency and profitability. ${ }^{8,9}$ A needs-based model is better designed to support healthy rangeland ecosystems and rural communities from the bottom up by considering the complex sociological elements of a family ranching operation. A needs-based model provides services and information that address the needs of a ranching operation to different members of the operation when they need or want such information $^{10,11}$ (Fig. 2). For researchers and manangers, this step involves recognizing and investigating the decision-making processes of land managers-women and men-that help them adapt to change and manage complex adaptive systems.

Another important step is to develop a research agenda that explores the contributions and challenges of women in rangeland management. Efforts like the Wyoming Women in Range program, and the many like it around the country, that serve the needs of women managers, could be informed by research that documents women's roles and decision-making processes. To formally incorporate women's voices we need to formally document these voices with regard to their perspectives as business operators, natural resource managers, wives, mothers, and off-farm wage earners.
Finally, we must identify what needs for, and barriers to, Extension programming exist for women. Barriers to Extension programming can emerge from women's diverse time commitments to community or family, the unique challenges of rural life, or from the traditional perception of women as "farm wives" who do not make management decisions. ${ }^{12}$ The growing recognition of women's role in rangeland science and management is an exciting opportunity for our field to support healthy rangeland ecosystems and rural communities by incorporating women's voices into rangeland research and Extension.

\section{Acknowledgments}

We thank Dr Maria Fernandez-Gimenez, Sally Leigo, and Dr Layne Coppock and two anonymous reviewers for their support in the development of this paper.

\section{References}

1. Allen, R., and G. Harris. 2005. Census of Agriculture. 2002 Census Publications. Demographics of US Farm Operators. National Agriculture Statistics Service, US Department of Agriculture. Available at: http://www.agcensus.usda.gov/Publications/2002/Other_Analysis/. Accessed 1 May 2013.

2. United States Department of Agriculture, National Agricultural Statistics Service. 2007. 2007 Census of Agriculture: Women Farmers. Available at: http://www.agcensus. usda.gov/Publications/2007/Online_Highlights/Fact_Sheets/ Demographics/women.pdf. Accessed 1 May 2013.

3. Farmar-Bowers, Q., and R. Lane. 2009. Understanding farmers' strategic decision-making processes and the implications for biodiversity conservation policy. Journal of Environmental Management 90(2):1135-1144.

4. Barrett, C. B., M. R. Carter, and C. P. Timmer. 2010. A century-long perspective on agricultural development. American Journal of Agricultural Economics 92(2): 447-468.

5. McGowan, C. 2011. Women in agriculture. In: D. Pannell and F. Vanclay [eDs.]. Changing land management. Collingwood, Victoria, Australia: CSIRO. p. 141-152.

6. Trauger, A., C. Sachs, M. Barbercheck, N. E. Kiernan, K. Brasier, and A. Schwartzberg. 2010. The object of extension: agricultural education and authentic farmers in Pennsylvania. Sociologia Ruralis 50(2): 85-103.

7. Vanclay, F. 2011. Social principles for agricultural extension in facilitating the adoption of new practices. In: D. Pannell and F. Vanclay [EDs.]. Changing land management. Collingwood, Victoria, Australia: CSIRO. p. 51-67.

8. Kessler, W. B. 1993. Evolution of range ecology practices and policy: back to our rangeland ecosystem roots. Rangelands 15(3):101-103.

9. Fulton, A., And F. Vanclay. 2011. Enabling change in family farm businesses. In: D. Pannel, and F. Vanclay [EDs.]. Changing land management. Collingwood, Victoria, Australia: CSIRO.p. 95-106.

10. Stephenson, G. 2003. The somewhat flawed theoretical foundation of the extension service. Journal of Extension 41(4). Avail- 
able at: http://www.joe.org/joe/2003august/a1.php. Accessed 1 May 2013.

11. McDowell, G. 2001. Land-grant universities and extension into the 21st century: renegotiating or abandoning a social contract. 1st ed. Ames, IA, USA: Iowa State University Press. 264 p.

12. Barbercheck, M., K. Brasier, N. E. Kiernan, C. Sachs, A. Trauger, J. Findeis, A. Stone, and L. Moist. 2009. Meeting the extension needs of women farmers: a perspective from Pennsylvania. Journal of Extension 47(3). Available at: http:// www.joe.org/joe/2009june/a8.php. Accessed 1 May 2013.

Authors are Graduate Research Assistant, Campus Mail 1472, Colorado State University, Fort Collins, CO 80523-1472, USA, hailey.wilmer@colostate.edu (Wilmer); and Extension Range Specialist, College of Agriculture and Natural Resources,
Dept of Ecosystem Science and Management, Dept 3354, 1000 E. University Ave, Laramie, WY 82071-2000, USA (Mealor). This publication was made possible through funding from an Agriculture and Food Research Initiative Competitive Grant from the USDA National Institute of Food and Agriculture Proposal 2009-04442; Colorado Agricultural Experiment Station COL00698 Advancing Adaptive Management of Colorado's Rangelands through Participation of Scientists, Managers and Community Members; USDA NRI Managed Ecosystem Project 2008-00725 Linking Ecological and Economic State and Transition Models for Adaptive Management of Western Rangelands.

Rangelands 35(6):36-40

doi: 10.2111/RANGELANDS-D-13-00032.1

(C) 2013 The Society for Range Management 